\title{
What kind of nation state will Greenland be? Securitization theory as a strategy for analyzing identity politics
}

Ulrik Pram Gad, ${ }^{1}$ Associate Professor of Arctic Culture and Politics, Aalborg University, Denmark

Arctic geopolitics is a moving target - and Greenland, determined to emerge as a sovereign nation state, is a particularly dynamic case. The choices currently made in language policy about how to prioritize the Greenlandic, Danish, and English languages will put Greenland on very different routes towards and beyond independence. The article modifies the analytical strategy prescribed by Copenhagen School Securitization Theory to produce a nuanced picture of national identity politics, the tensions involved, and scenarios for the future.

Greenland might be an enormous island, but it is also a people of only 56,000 persons. As such, it will be in need of partners and allies in most of the fields in which a modern nation state and welfare society engages: goods ranging from foodstuff to industrial machines, services ranging from education to military alliances, and human resources in most specialized trades. Given the way in which current global upheavals in both climate, power, and commerce change Greenland's position on the globe, a sovereign Greenlandic state will not be acting in a vacuum when choosing where to shift its dependencies. Nevertheless, a prognosis of Greenland's future maneuvering in Arctic and international politics must take as its point of departure the way in which Greenland envisions its core identity. Independence, according to Greenlandic identity discourse, is meant to allow the

\footnotetext{
${ }^{1}$ I am grateful for comments on an early version of this paper from Iben Bjørnsson, Martin Breum, Danita Burke, Naja Graugaard, Victoria Hermann, Marc Jacobsen, Uffe Jakobsen, Lars Jensen, Jon Rahbek-Clemmensen, and an anonymous reviewer for Politik. The basic arguments of this article - both concerning analytical strategy and Greenlandic national identity - hark back to my master's thesis analysing the 2002 Greenlandic debates on language, available as Gad (2005). The central conclusions of that part of the empirical analysis were published in English in (Gad 2009a), and the acknowledgments extended in Gad (2005, fn. 1) still apply. A more detailed version of the 2016 empirical analysis presented in this paper is available in Danish in Gad (forthcoming).
} 
unfolding of Greenland's true self, free from colonial domination. However, what can this self-identity tell us about the course of a future Greenlandic state?

Decades of philosophical, historical, sociological, and anthropological research into nationalism has taught us that even if cultural and political similarities and differences might be coalescing, national identity does not exist (Fink 1991). Only national identification exists (Brubaker and Cooper 2000, 14ff; Hall 1996, 2) as a re-iterative, Janus-faced process: 'We' identify with characteristics and ideals which each of 'Us' believe our compatriots to share - while defining ourselves in contrast to traits and ideals we believe characterize 'Them'; others, who are not 'Us'. However, rarely do we agree on the specifics of our identity nor on what differentiates 'Us' from 'Them'. Even if ethnographers, scholarly and lay, have produced detailed accounts of 'Eskimo culture' and 'Greenlandic political culture' with no consensus, the future course of Greenland is determined by a political negotiation of 'who we are' and how to realize the ideal. Current debates about language policy are, at the core, about 'whom we should be.' The choices made in these negotiations about how to prioritize the Greenlandic, Danish, and English languages will put Greenland on very different routes towards and beyond independence.

Empirically, this article shows how a future sovereign Greenlandic state will set out to be a democratic welfare state. But it also shows how it will face internal struggles over the character of its democracy and society: whether it will be a linguistically exclusive community risking its character as a Nordic welfare society, or if it will be an inclusive community reneging its cultural identity. In providing this analysis, the article demonstrates how one may appropriate the analytical strategy prescribed by Copenhagen School Securitization Theory (hereafter CSST) to produce a nuanced picture of national identity politics. The focus of the analysis is on public and political debates on language policy, since both Greenlanders and scholars agree that the command of kalaallisut [the Greenlandic language] has for more than a century been core to discussions about what constitutes Greenlandic identity (Thomsen 1996, 270; Sørensen 1994, 108; Sejersen 1999, 126ff; Langgård 2002, 77). After introducing a few basic elements of how nation, state, language, and identity relate - in theory and in Greenland - the article offers an approach to modify the CSST apparatus for analyzing identity politics. The article then moves on to analyze three pairs of threat narratives present in the Greenlandic debate on language: Two threats to democracy; two threats of exclusion, continuing to take aim at the overall evolution of Greenlandic society; and, finally, two radically different ways of articulating the English language in order to escape the dilemmas and tensions produced in the bilateral relation between Greenland/Denmark. The article concludes by formulating three scenarios for how a potential sovereign Greenlandic nation state could constitute itself linguistically - prioritizing Greenlandic, Danish, or English - and how the linguistic constitution would influence the international relations in the Arctic region. 
Nation, state, language, and identity in theory and in Greenland

In the Arctic, both the modern state and the concept of nation arrived rather late - and white colonizers imported both (Dahl 2016; Thuesen 1988). In Greenland, the notion of sharing an identity, whether national or ethnic, as Greenlanders was the result of meeting qallunaat [white people]. Since Denmark gradually became capable of enforcing the monopoly it granted itself on trading in Greenland, Danes became the qallunaat in relation to whom Greenlanders defined their identity (Sørensen 1994, 109; Dorais 1996, 29). As self-appointed naalagaat [those who decide over others], Danes came to take up the position of the radical other of Greenland: the other which at once constituted and compromised Greenlandic identity (cf. Žižek 1992, 197; Wæver 1994, 18). Upon their arrival, the Danes decided that vis-à-vis Greenlanders, difference needed to be upheld. Greenlanders would be best off by sticking to hunting seal (and the Danish fur trade would benefit too). Meanwhile, the nation building process, which took place during the $19^{\text {th }}$ Century in a number of European countries, was copy-pasted in Greenland with surprisingly little delay, and with an important linguistic twist compared to other colonial societies. According to Danish theologian N.F S. Grundtvig, national elevation (the only true way to relate to God) demanded the education of the common man in his own language. In Greenland, this meant the education of Greenlanders as catechists, capable of receiving education via the Danish language, in order to teach both the gospel and general enlightenment in Greenlandic to their compatriots along the coast. This new class of hybrids became parties to the early 1900 kalaaliussuseq-debate [on what constituted Greenlandic identity] conducted in the Greenlandic newspapers. Here, the traditional elite of piniartorsuit [great hunters] argued (agreeing with the Danes) that being expert sealers was what distinguished Greenlanders. In the end, however, the new intellectual class (the catechists) was included in national identity; fluency in the language of the land became accepted as a central criterion for being Greenlandic. ${ }^{2}$ A century later, command of the two languages is still central "in this ethno-political universe [where] Greenlandicness and Danishness are experienced and used as each other's negation" (Sørensen 1991, 48; my translation.).

Identity does not pre-exist by itself. Rather it has to be produced and reproduced in an ongoing negotiation. Each idea of someone being identical is the result of a contingent process in which some traits are prioritized over others; i.e., a political process. In the politics of identity production, two mechanisms work in tandem: reification and securitization. You point out something as threatened and thereby affirm and solidify the existence of this something in the first place (Wæver 1994; Buzan et al. 1998, ch. 6). The basic story told in Greenlandic identity discourse is one that takes its point of departure in noting how Danes caused the decline of original Inuit culture. Even if a Greenlandic elite cheered, ${ }^{3}$ 'development' and 'modernization' are essentially apprehended as 'Danish'. Hence, in scholarly analyses as well as in public debates in both Greenland and Denmark,

\footnotetext{
${ }^{2}$ For the details and effect of the kalaaliussuseq debate, cf. Petterson (2014); Langgård (2003).

${ }^{3}$ Like elites elsewhere in the later stages of colonial projects, cf. Manniche (2003).
} 
the relation between modernization and Greenlandization is often presented as a dichotomous choice: Either you do the one, or you do the other. This conclusion is apparent if one focuses on language. Part of integration into the Danish state in 1953 was the prioritization of the Danish to secure modernization. Integral to the introduction of home rule in 1979 was giving priority to Greenlandic.

In effect, the result was a dual track primary education system, presenting parents and teachers at particularly urban schools with the choice of putting children in Greenlandic or Danish classes. Often teachers and parents, Greenlandic or mixed Danish/Greenlandic couples, prioritized the Danish language with a view to securing their children the best options for further education. In smaller settlements, the language of instruction depended on what teachers were available. In the 50's and 60's, teachers mainly consisted of Danes; currently, teachers are mostly Greenlanders. No reliable statistics exist on the language capabilities of the Greenlandic population, but, roughly speaking, the majority of the population (particularly outside the capital, Nuuk) is by now functionally monolingual Greenlandic speakers, with a large minority more or less bilingual and a rather small, but mostly well-educated minority speaking Danish but not Greenlandic (Arbejdsgruppen 2002, 30; Gad 2005). English competencies more or less follow Danish competencies and the general level of education.

This predicament sits uneasy with the ideal, imported from Denmark, that the best way to be part of the world involves having your own culturally homogenous nation state ( $\mathrm{Gad} 2016)$. The point of departure to demand Greenlandization remains the decline of an original Inuit culture faced with Danish colonization. But no one wants to return to pre-colonial hunting culture. Rather, Greenlandic national identity discourse involves the standard nationalist idea that resurrecting the fallen, golden past in the future can only conclude in the form of a nation state, and this involves development and modernization. The Greenlandization narrative needs to articulate symbolic elements of Inuit culture particularly language - to elements of modernity: formalized education, outboard motors, and the internet. Greenlandization means modernization performed in Greenlandic rather than in Danish. However, picking the right elements of tradition and modernization is fraught with dilemmas and tensions. Particularly after securing Danish acceptance of the formal right to secession in 2009, political debates in Greenland have turned to ways of finding alternative sources of revenue to escape dependence on the annual 'block grant' from Denmark. After the hype of a mining adventure was academically debunked (Rosing et al. 2014), whether politically accepted in Nuuk or not, an oil bonanza is left as the only credible shortcut to a self-supporting economy. However, the intensified ambition to shift Greenlandic identity politics away from focusing solely on the bilateral relation to Denmark has involved a re-articulation of some of the dilemmas and tensions. When analyzing both the shift and the underlying dilemmas and tensions, Copenhagen School securitization theory offers valuable tools. 


\section{Reading identity politics as threats and defense}

The authoritative Copenhagen School definition of a securitization (Wæver 1995; Buzan et al. 1998; cf. Jacobsen and Herrmann this issue) involves the participation of two distinct actors. A securitizing agent performs a 'securitizing move,' a statement rhetorically constructing an existential threat to a valued referent-object while advocating an extraordinary measure to avert the threat. And a relevant audience accepts that this extraordinary measure may be adopted. If both elements, move and accept, are present, a successful 'textbook' securitization has occurred and the social situation of the issue at hand has changed from a politicized or even a non-politicized to a securitized one. However, the basic proposition of this article is that focusing only on successful securitizations is an extravagance we should not allow ourselves. Of course, the Copenhagen School is correct in stating that 'security' constitutes a realm both exclusive and explosive, hence, it is important to know how any specific subject has indeed come to be securitized. We can learn more from studying unsuccessful or partial securitizations. First, less-than-successful securitizing moves provide important information about how to avoid full securitization, not least because even less-than-successful securitizations may spark security dynamics (Wæver 2009b). Second, the close relation between security and identity (Wæver 1994; Buzan et al. 1998, ch. 6) means that the rhetorical figure at the core of a securitizing move may serve as a valuable lens for studying political identity negotiations. If done in a structured way, this may feed into analyses of not just security dynamics but also the dynamics and results coming out of identity politics - i.e., the political construction of identities. In other words: by listening to what is pointed out as threats to what, we may learn what is important to an identity in question. By looking at how threats and measures to their aversion are constructed in relation to valued referent-objects, we can learn about how identities evolve.

In contrast to an 'orthodox' implementation of Copenhagen School analytical strategy, this article makes three amendments. First, we relax the demand that threats need to be existential and measures extraordinary. Both thresholds, extraordinary and existential, are conceptually challenging to define and have proven problematic to establish in empirical analyses. ${ }^{4}$ Second, we observe the sequences of measures-threats-referent-objects as narratives. In a formal sense, measures have the same relation to threats as threats

\footnotetext{
4 The distinction between existential and 'non-existential' threats very much depends on the definition of the referent-object: Any threat can be taken as existential in relation to a referent-object specified in the 'right' way. A malaria mosquito may credibly be pointed out as an existential threat to the life of a human being. A regular mosquito could be posed as an existential threat to the wellbeing of a human being. A swarm of mosquitos may pose an existential threat to the possibility of enjoying spectacular Greenlandic nature - and to the tourism business. And because of the paradoxical character of identity, it is impossible to dismiss up front that any potential diacriticon will be pointed out as essential to the identity at hand. For instance, the Greenlandic language lacks its own name for numbers from 13 and up. A politician explicitly points out the fact that Greenlandic speakers use Danish numbers as a threat to Greenlandic identity (Inatsisartut 2002.04.19, 60). In theory, only the audience can decide whether it accepts this threat as existential for the referent-object in question (Buzan et al. 1998, 31). In parallel, the operationalization of the limit between 'normal' and 'extraordinary' "remains insufficient" for application by analysts, wherefore "[i]n
} 
have to referent-objects. When pointing out a threat, you prognosticate a negative effect of something on a referent-object. When suggesting a means to avert a threat, you prognosticate or promise that the means will have a negative effect on the threat. Moreover, the measure will have an indirect, positive effect on the survival of the referent-object. Hence, the analytics employed in this article read CSST's rhetorical figure of 'measuresthreats-objects' as a narrative chain of causes and effects that, in the end, point out a valued referent-object. When an argument advocates measures against threats (or just points out threats), it only works rhetorically with an audience because the referent-object is valued because who 'we' are is important. In a final step, we tend to the reaction of the audience. However, contrary to a basic securitization analysis, we are not (only) interested in whether an audience confirms or completes the process of securitization by accepting the possible use of extraordinary means. ${ }^{5}$ Rather, like in a more advanced CSST analysis

the application on concrete cases, quite hopeless debates often emerge on whether something is 'ordinary' or 'extra-ordinary'." (Wæver 2003, 26; cf. Werner 1998). However, as we will see below, the delimitation of the ordinary is not just a technical problem for the analyst; often the question of whether a proposed means is ordinary or extreme is core to the empirical politics. E.g., a denial of voting rights to people who only speak Danish constitutes an extraordinary suppression of basic democratic rights, provided that one brings to the table a concept of democracy based on individual rights. But the same denial constitutes a natural and ordinary way of respecting and upholding the cultural specificity of a people - if the point of departure is a concept of democracy based on the rights of an ethnically defined community.

\footnotetext{
${ }^{5}$ This amendment relates to critical discussions of CSST, however, the position taken in this article is only feasible because the object of study is not security per se, but identity politics. CSST advocates a focus on the illocutionary force of the speech act: a securitizing speech act is complete and successful if an audience is compelled to accept a hypothetical implementation of extraordinary means. Hence, the audience is at once decisive (Wæver 2003,11) and passive: only if a relevant audience explicitly denies accept, the analyst may safely conclude that the securitizing move was not successful (Buzan et al. 1998, 26; cf. Derrida 1982, 8; Austin 1997, 65). Moreover, more than one audience may show itself to be relevant by denying accept of a proposed extraordinary means (cf. Wæver 2003, 26; Roe 2008). If the Greenlandic parliament adopts an extraordinary measure - e.g., prohibiting members from speaking Danish in parliament - the electorate may show itself to be a relevant audience denying accept at the next general elections. Or the Danish state may, in the form of the Danish High Court denying the constitutionality of the decision. Or an international body like the European Court of Human Rights. The present article escapes these complications by focusing on the perlocutionary consequences of the construction of threats and defensive means; i.e., the explicit responses to such claims. One strand of critique takes the CSST focus on the illocutionary force of a securitizing speech act to deny the relevance of the audience (cf. Gad and Petersen 2011). It claims that Wæver's concept of security equals Schmitt's concept of politics, and warns that both involve the idea that agency is concentrated in one authority able to assert its will top-down: A powerful actor installs security by declaration. As an alternative to this (skewed) rendition of CSST, critics advocate and produce analyses accounting for all the little acts of small agents or for the underlying structures, which co-produce a given securitization (Gad and Petersen 2011). Such self-proclaimed 'sociological' securitization analyses, of course, are valuable in directing attention towards minor agents to hold accountable for unjust distribution of insecurity and towards structures to change to escape surveillance and mal-governance. However, applying securitization theory - whether in the 'sociological' version or à la Wæver - as a checklist for successful securitization misses one important point: unsuccessful and partially successful securitizing moves and outright misfires also provide valuable information for understanding security dynamics (Wæver 1995). Moreover, it allows us to understand important dynamics of broader identity politics. First, because interactive dynamics may arise from less-than-successful securitizations. Second, less-than-perfect securitizing moves may tell us about the limits of identity discourses and how they are negotiated. In combination, interactive dynamics and discursive limits provide the foundation for building prognoses of future politics. Recent ST writings by Wæver seem to be bifurcated. Either an article is more or less explicitly engaged in an exchange with the 'sociological version' of ST defending an illocutionary version of speech acts of securitization and a
} 
of dynamics of securitizations, the 'audience' is relevant also when suggesting alternative narratives of cause-and-effect, pointing out other threats, means and/or referent-objects (whether or not this amounts to formal counter-securitizations by posing alternative existential threats and extraordinary means). The point is, that alternative narratives of cause and effect point out alternative referent-objects as valued, indicating alternative identity constructions.

Scholarly consensus insists that the Greenlandic language is 'alive and well', particularly when compared with other indigenous languages. ${ }^{6}$ Nevertheless, securitizing moves that point to Danish language as a threat is a recurrent feature of Greenlandic politics. This observation confirms the image of Denmark as Greenland's threatening other. However, casting the analytical net just a little bit broader and reading the debate on language policy and threats comprehensively point to other referent-objects that make for a much more nuanced image. This provides us with more information to use when trying to understand just what a future Greenland might aspire to be. The remainder of this article analyses the 2002 and 2016 debates on language in the Greenlandic parliament (Inatsisartut) and newspapers (Sermitsiaq and $A / G$ ) through the CSST lenses as modified above. $^{7}$ On the one hand, the years 2002 and 2016 are not special. Language policy is a recurrent issue in debates on how to realize the best kind of Greenland. On the other hand, the formal change of status for the Greenlandic autonomy arrangement in 2009 involved a formal change of status for the Greenlandic language: Whereas the 1978 Home Rule Act declared that, "Greenlandic shall be the principal language. Danish must be thoroughly taught. Either language may be used for official purposes." (section 9), the 2009 Self-Government Act declares Greenlandic to be "the official language in Greenland" without mentioning the Danish language. Moreover, Inatsisartut in 2010 adopted a longdebated Act on language policy aiming primarily to "secure the Greenlandic language as a language, complete and supporting the society" (section 1) by prescribing that all public agencies and private enterprises employing more than 10 persons formulate a language policy (section 4) and by awarding every resident in Greenland the "right to learn Greenlandic and Danish as well as a language of international reach". ${ }^{8}$ However, the shift of focus for the overall debate on the next steps towards independence, from formal recognition and self-government to substantial self-support in terms of economy and human resources, appears to have made more of a difference to the way weights have shifted between the threats pointed out, the means suggested, and the definitions of Greenlandic identity promoted. Below, a few central threat constructions will be explicitly dissected

collective interpretation of Austin's account of illocution (Wæver 2011; 2015). Alternatively, it employs securitization theory in analyses of security dynamics playing out as series of speech acts from different securitizing agents (Buzan and Wæver 2009; Wæver 2009a; Wæver 2009b; Wæver and Sheikh 2012).

${ }^{6}$ Arbejdsgruppen (2002, 36); Langgård (2003, 215); A/G (2016.12.07, 2); Langgård in A/G (2016.12.07, 4).

${ }^{7}$ Gad (2005, ch. 3.3.1) discusses the delimitation, drawbacks and benefits of selecting this archive for analysis.

${ }^{8}$ The 2010 Act does retain the 1978 formula that "The Danish language may be used for public purposes." (section 3), however, contrary to 2009 , the possible reform of this status is a purely internal matter for Greenland. 
according to the reading strategy developed above; but most of the analytical work will be presented in a synthesized form. ${ }^{9}$

Pointing out threats in Greenlandic debates on language

As part of 2016 Inatsisartut deliberations on the import of foreign workers, MP Hans Enoksen put forward the ambitious "final demand" that, "you have to be able to speak Greenlandic to have a job in the public sector. This will strengthen our identity. ... In this way, we will create a proud people working for its own country. In this way, we can establish the state of Greenland." ${ }^{10}$ Even if Enoksen did not name it explicitly, in the context of decades of debate it is clear that a threat comes from the Danish language. Interventions in parliamentary and media debate frequently point out the position of the Danish language in most formal institutions in Greenland as a threat to the interests of individual Greenlandic speaking monolinguals. It is difficult or impossible to get jobs in the public and private sector or to get an education if you only speak Greenlandic because 'the system' speaks Danish. However, as Enoksen makes clear, the referent-object of the threat goes beyond the individual. The way in which Danish language has pushed aside Greenlandic threatens both national pride and the ability of Greenlanders to work for the realization of their national ambition. Enoksen's demand may be comparatively ambitious, but it resonates with well-established narratives about threats, valuables, and defensive means.

Nevertheless, almost a decade of 'Self-Government' focusing on economic diversification and limiting economic dependency to prepare for formal independence have re-configured the Greenlandic debates on language. Even if most narratives of threats and defense remain recognizable from earlier years, Enoksen's position is indicative of the way in which the weight seems to have shifted in the debate. In 2002, Enoksen was the newly elected chair of the ruling social democratic Siumut party, and the campaign before the general elections in December that year was dominated by his low-voiced support for the principle, long pushed mainly by the left-wing nationalist Inuit Ataqatigiit party, that the Inatsisartut rostrum should be reserved for the Greenlandic language. In 2016, he was leading Partii Naleraq, a small but vocal opposition party, pushing an ambitious demand concerning most of the Greenlandic labor market. Meanwhile, the language debate preoccupying both parliament and press concerns whether and how to introduce English as the second language instead of Danish. In what follows, the article presents three closeups of three configurations of threat constructions:

- the threats conjured up to delimit the Greenlandic nation eligible to take part in democratically determining its own future;

\footnotetext{
${ }^{9}$ Detailed empirical references documenting the 2002 and 2016 analyses respectively are available in Gad (2005) and (forthcoming).

${ }^{10}$ Enoksen in $\mathrm{A} / \mathrm{G}(2016.10 .19,12)$; Inatsisartut $(2016.10 .12,49)$
} 
- the threats posed from linguistic (in)competencies towards the dual processes of Greenlandization and modernization, both necessary to realize a future Greenlandic nation state;

- and the recently promoted switch to English as a way of escaping the latter dilemma.

\section{Greenland - ethnic or civic democracy}

From the arguments put forward during the 2002 electoral campaign in support of the demand that the Inatsiartut rostrum should be reserved for the Greenlandic language, one can read an idea of democracy as tightly connected to an ethno-cultural community. The members of such a community have the right to decide its own future without outside interference. The regular use of the Danish language is presented as a threat to both important qualities of Greenlandic identity and to the Greenlandic people's hard-won ability to protect them, "we have now [acquired] home rule, because we .... wanted to take care of our culture and language ourselves, and to strengthen them" (Heinrich in Sermitsiaq 2002.11.15, 22). However, the demand sparked a storm of reactions. Opponents described the exclusion as a threat to both democratic values and to the quality of democratic debate. Primarily, the demand was described as a threat to individual rights to be heard by and take part in a democratic, political process. Namely, "our democracy" will be threatened if "Danish speakers are denied their fundamental right to express themselves" (A/G 2002.11.05, 2).

These two narratives, about Danish language as a threat to ethno-cultural democracy and about the prohibition of the Danish language as a threat to individual democratic rights, feed into each other. Any articulation of one narrative challenged the foundation of the other and vice versa. The realization of ethno-cultural democracy threatens the democratic rights of Danish speaking monolingual individuals. If the rights of Danish speakers are accommodated, the ethno-cultural ideal of democracy is compromised. On the one hand, the civic and the ethno-cultural narratives agree that democracy and democratic debate is a referent-object so valuable that it needs to be defended. In that sense, being a democracy is part of Greenlandic national identity: No-one imagines a future Greenland that is not democratic. On the other hand, the two narratives clearly disagree about what constitutes democracy, or rather, about how to delimit the community which must be democratic. Is the future Greenlandic democracy for everyone who live in Greenland, or is it for those who fulfil certain linguistic or ethnic criteria making them legitimate Greenlanders? This disagreement installs a tension in Greenlandic identity discourse between the universally accepted 'democracy' and the traditional diachriticon 'Greenlandic language'.

National welfare - Greenlandization and/or modernization

Pointing out Danish language as a threat to individual Greenlandic speakers opens two solutions, an individual and a collective. First, the threat may be interpreted in such a way that it is not 'the Danish speaking system' which constitutes the threat, but rather the fact 
that the individual in question is monolingual, the societal solution to which is then to teach individuals Danish in more efficient ways. However, the Danish language is pointed out as a threat to more heavily loaded referent-objects than individuals. At its most basic level, Danish language is presented as a threat to the Greenlandic language as such: The presence of Danish impedes the development of Greenlandic to function in certain sectors of society. Such 'domain losses' contribute to the threat against the formal position of Greenlandic, and this in turn is a threat to the dignity of the Greenlandic language. Particularly, its dignity is threatened when Danish migrants and Danish speaking Greenlanders "couldn't be bothered" (Poulsen in Sermitsiaq $(2002.02 .15,28)$; Matthiassen in Sermitsiaq (2002.05.03, 26); Heilmann in Sermitsiaq (2002.11.28, 38). Learning to speak Greenlandic. As "the Greenlandic language is our soul" (Olsen in Sermitsiaq 2002.11.22, 41 ); cf. Sørensen $(1994,109)$., the threat to the function, position and status of the Greenlandic language really take aim at the identity, equal worth, and dignity of the Greenlandic people. Indeed, a Greenlander has the right to be able to live a life with the language of the land only. The Greenlandic and Danish languages need to have equal status, not on Greenlandic territory, but equal in being superior in each their territory. The conclusion to this narrative, describing the second, collective solution to the threat coming from lack of Danish competencies vis-à-vis a Danish speaking 'system', is a total linguistic Greenlandization of education, administration, and businesses.

However, the narrative of Greenlandization clashes with a narrative of modernization. At the basis of this narrative is the impression that the Danish language is a precondition for knowledge and vision in general and for education in particular. Next, vision and education is presented as a precondition for employment at an individual scale and for enterprise at a societal scale. The narrative reached its climax when the lack of capabilities in the Danish language was pointed out as a threat to Greenland's development towards emerging as an independent welfare state. Specifically, the narrative of exclusion of Danish speaking monolinguals voiced in opposition to the reservation of the Inatsisartut rostrum continued along this line, since their exclusion would mean that individuals migrate to Denmark or do not repatriate after studying abroad. Even without brain drain, exclusion may threaten the quality of democratic deliberation. Further, low quality deliberation means low quality solutions to a host of specific societal problems, and consequently less development and less welfare. Like democracy, welfare is a referent-object worth defending. Welfare is an indispensable element in Greenlandic identity (cf. Langgård 2003, 250; Larsen 1992, 223).

Modernizing without the Danish language

So, on the one hand, renouncing on being a modern welfare state would contradict Greenland's basic vision of itself. On the other hand, the main medium both for abstract modernization and for concrete manning of the welfare state, the Danish language is, constitutively per definition, a threat to Greenlandic identity. No surprise, then, that a classic 
(Engell 1982, 168f) discussion within the overall Greenlandic debate on language concerns the possibility of accessing the joys of modernization via English rather than Danish. No consensus exists on the subject, however. In 2002, the English language was routinely mentioned as a road to modernity along the Danish one, and at times as an occasional add-on to Danish when mentioning the need to facilitate openness to secondary and tertiary education. However, in 2016, a new turn of the narrative had moved the Danish language to the role so far reserved for the Greenlandic, namely that of a provincial language threatening to limit Greenland's access to global modernity. Correspondingly, the English language ascended to the role of primary means to mend that threat. The coalition agreement claimed that, "we as a nation will be in a stronger position by having a world language as second language. Such a change will bring us closer to the goal that Greenland should have more options to choose from globally and in commerce" (Olsen in Sermitsiaq 2002.11.22, 41); cf. Sørensen (1994, 109). A couple of young Siumut members explained the connection between Danish and English, "The Danish language is dominating too much in Greenland and it is directly impeding when it comes to communicating with the rest of the world ... [T] he Danish language is directly the cause for many Greenlanders having difficulties in learning English". ${ }^{11}$ Hence, a Siumut MP proposed that English should substitute Danish as primary foreign language, arguing that, "The children and the young ones are our future. Therefore, it is only natural, that we open their world out towards the gates of the great outer world, since this is the only way we can harvest a better and updated knowledge in the future." ${ }^{12}$ A Siumut spokesman laid out the proportions, "[T] he Danish language is a language for six million Danes. But a billion people around the world understands the English language" (Langgård in $\mathrm{A} / \mathrm{G}$ 2016.12.07, 4).

A host of words of caution were issued in opposition in both parliament and press. Added to threats of exclusion of Danish speakers were warnings about Greenland losing access to free education in Denmark, and that neither the teachers nor schoolbooks were anything near ready. More radically, English was presented as a threat to Greenlandic language and identity more powerful and severe than Danish:

"English is already washing over the society as a flood. At worst, the dikes may break and flood the Greenlandic language ... If a central decision to decisively embrace English is taken, one just need to know that one will be nourishing a snake in one's bosom. I do not know a single minority language in the world that has survived alongside the English". (Langgård in A/G 2016.12.07, 4)

\footnotetext{
11 Johansen \& Sandgreen in sermitziaq.ag (2016.03.16). Accessible at: http://sermitsiaq.ag/siumutungdom-danske-sprog-haemmer [Accessed 3 July 2017].

${ }^{12}$ Motzfeldt in Inatsisartut (2016.04.21/38) (clash of metaphors in org.)
} 
Nevertheless, an ensuing Inatsisartut debate concluded that English could be introduced in the first year of primary school alongside Danish. The Minister for Education, representing the moderate Demokraatit party which was briefly a coalition partner, even suggested that the point of departure for her follow-up on the debate would be to implement the change within two years.

Conclusion and perspectives: Kuwait, Luxembourg, or Iceland?

Greenlandic identity revolves not only around 'Greenlandic culture.' It also includes democracy, sovereignty, and, in particular, welfare. Greenlandic identity politics is all about how to combine which symbolic elements of a 'native' Greenlandic culture with these elements of modernization. A future sovereign Greenlandic state will set out to be a democratic welfare state. But the use of Danish language is seen as a threat to the dignity and integrity of a Greenlandic nation imagining its true incarnation to be culturally homogenous and, thus, speaking Greenlandic. Greenland is facing tough struggles with itself over the character of its democracy and society. The attempts to combine indigeneity and modernity create important tensions that then appear in the discourse. Particularly, when the demand for prioritizing Greenlandic language is put forward in absolute ways, tensions arise in relation to welfare and independence. One option is that Greenland insists on being an ethnically defined nation. This would imply that it risks its welfare character by pushing away people who only speak Danish, including immigrants from the former colonial power and even more problematically Danish speakers who consider themselves Greenlanders. Another option would be fully to convert itself into a civic conception of nationhood, including all citizens on equal terms regardless of linguistic competence. This would mean putting at risk the cultural identity legitimizing and spurring the quest for independence in the first place.

The article specified this fundamental dilemma by applying a strategy for analyzing identity political negotiations, developed by modifying CSST, on Greenlandic debates on language, a core element in Greenlandic identity discourse. On the one hand, this analysis alone cannot form the basis of predictions for how the future of a Greenlandic state will be. First, because it has dealt only with the self-perception and ideals of Greenland without taking into account the perceptions and ideals of neighbors and more distant relations. No nations form their future in a vacuum or unilaterally re-casts the globe in their own image (even if one could get that impression from listening to national political debates). On the other hand, no scenarios of a future Arctic would be valid without taking into account the specific aspirations and ideals of Greenland. Second, the analysis presented has limited itself to one topic: language policy. This is only one of a series of discussions decisive for the future course of Greenland, but it is indeed a fundamental question. Both because it represents deeply sedimented parts of the self-image of Greenland and implicates almost all sectors of society. Moreover, the choice and priority of languages have severe consequences for what kind of society may materialize, and how it will engage the international as part of a new Arctic. 
To build scenarios, parallel cases may serve as a guide. Parallels are never perfect because every case is unique. However, it appears particularly difficult to find a relevant 'peer group' of which to make Greenland a case. A population similar in size to the smallest sovereign islands, typically scattered in tropical seas, only Greenlanders inhabit stretches of the coast of an Arctic island almost the size of India (home to a billion people) or the Caribbean Sea ('home' to 13 sovereign states and 15 more or less self-governing dependencies). Nevertheless, for the sake of opening up our imaginations (Øverland and Neumann 2004; Gad 2009b), rather than comparative analysis, three countries could serve as 'end points' for three narratives continuing from where the Greenlandic debates on language is at present. All three continuations work on the (fragile) condition that Greenland finds ways to both finance welfare (i.e., strikes oil) and develops human resources. In real life, of course, these conditions intertwine intimately with the question of language, but to focus attention on one important choice (that of language), we bracket everything else.

Default must always be a status quo scenario. In this case, default means prioritizing the teaching of and in Greenlandic while paying lip service to the importance of a second language. If Greenland continues the linguistic policies of the last three decades and suddenly hits a major oil deposit, Greenland will be the Kuwait of the Arctic. Greenlandic welfare will be secured; all Greenlanders will be at leisure. Formally, Greenlanders will be in charge, but substantially expat experts will run the country, probably most of them on relatively short contracts. Possibly, there will be a quite high level of corruption and slack, but no one cares. There is enough for all Greenlanders, and the expats do not need to commit as they are looking to move on. Below, a huge proletariat of disenfranchised foreign menial workers not socially integrated. In terms of geopolitics, such a linguistic and ethno-political strategy would make Greenland like most third world countries dependent on one or a few natural resources, as free to switch allegiance from one super power to another as the constellation of superpowers of the day allow.

If Greenland adds fluency in Danish to Greenlandic, Greenland will be an Arctic equivalent of Luxembourg. Attractive to Scandinavian and Icelandic immigrants and ambitious in integrating them. On the one hand, such a multicultural elite will be in charge of the country in a more solid way. Like in Luxembourg, the elite might combine its dualintegration (abroad and in Greenland) and the sovereignty of Greenland to siphon resources from the neighbors into the country. On the other hand, the elite will be less distinct and deeper integrated with neighbor countries (in Greenland's case the Nordic countries). The foreign proletariat will probably also exist in this scenario, but it might be a little bit less isolated as some of it may come in via Scandinavia, fluent in a language usable also in Greenland. Geopolitically speaking, such a Greenland would continue to be oriented towards Europe (possibly even better integrated informally) and likely to be less left as much alone by other power centers as today (i.e., within a US sphere of interest with or without a Danish buffer).

Finally, if Greenland succeeds in substituting English for Danish as a second language, and does so in a sufficiently solid way that most Greenlanders are functionally bilingual, Greenland will be like Iceland. Greenlanders will be open for business with 
most of the world without intermediaries and, thereby, directly in control, as far as its educational resources take it. It will be necessary to recruit the most specialized human resources on a global labor market, but it will be easier to do so because the imports will not need to integrate fully linguistically. Hence, Greenland will still be an ethnically distinct 'members only club', as outsiders will not really be able to know what is going on behind the linguistic doors. Again, supplemented with a foreign proletariat, easier to integrate (more or less) in select individual cases via English, but also easier to segregate en masse. This Greenland is likely to be drawn into Anglo-Saxon North America, particularly as it gradually unravels its special ties to Denmark and, thereby, Scandinavia and Europe, while forgetting the Danish language.

In 2016, a parliamentarian majority in Greenland seem to prefer prioritizing English. However, replicating the Icelandic success appears a daunting task, taking into consideration the radically different points of departure for the two countries. The then Minister of Education of Iceland in 2014 explained how the switch to English was really just a formalization of a practical process more or less completed:

"It was not until 1999 that English switched places with Danish to become the first foreign language taught in the Icelandic school system. Long before that, however, English had become the foreign language that received the greatest attention in the educational system and held a unique position when it came to stimulation and pupils' motivation. For years now, children have been strongly motivated to learn English by their surroundings." (Minister of Education 2014).

Contrast this to a recent evaluation of the Greenlandic primary school, reporting how, "a teacher and a superintendent from two small towns say: Danish and English are hard, because they [the pupils] do not meet [those languages] in their everyday life." (EVA 2015, 44).

However, the broad acceptance of the idea suggests that a narrative has been established which would allow Greenlandic identity to unfold in the form of a modern, national welfare state without negating itself by being dependent on the Danish other. As such, the narrative will come back to haunt the politicians every time an evaluation tells them that their latest school reform did not make it either. Making the human resources meet the ambitions remains the toughest challenge on Greenland's road to independence.

Bibliography

$A / G$, bi-weekly, volumes 2002 and 2016

Arbejdsgruppen for Sprogpolitisk Redegørelse. (2002). ...men ordet. Sprogpolitisk Redegørelse. KIIIP. Nuuk.

Austin, J.L. (1997 [1962]). Ord der virker. Gyldendal: Copenhagen. 
Brubaker, R. and Cooper, F. (2000). Beyond "identity". Theory and Society, vol. 29(1), pp. $1-47$.

Buzan, B., Wæver, O. and de Wilde, J. (1998). Security. A New Framework for Analysis. Boulder, CO: Lynne Rienner.

Buzan, B. and Wæver, O. (2009). Macrosecuritization and Security Constellations: Reconsidering Scale in Securitization Theory. Review of International Studies, vol. 35(2), pp. 253-276.

Dahl, J. (2016). Seeing like a state in a society of states: the social role of science and technology in the northward expansion of the international society, unpublished $\mathrm{PhD}$ thesis. Department of Political and Social Sciences, European University Institute, Firenze.

Derrida, J. (1982 [1972]). 'Différance', in Margins of Philosophy, University of Chicago Press, Chicago, pp. 1-28.

Dorais, L.-J. (1996). Inuugatta inuulerpugut: Kalaallit and Canadian Inuit Identities. In: B. Jacobsen (ed.). Cultural and Social Research in Greenland 95/96. Essays in honour of Robert Petersen. Nuuk: Ilisimatusarfik/Atuakkiorfik, pp. 28-33.

Engell, M. (1982). Ét land - to sprog. Dansk $i$ Grønland, unpublished MA thesis. Institut for Dansk, University of Copenhagen.

EVA. (2015). Grønlands Folkeskole. Evaluering 2015. Danmarks Evalueringsinstitut. Copenhagen.

Fink, H. (1991). Identiteters identitet. In: H. Fink and H. Hauge (eds.). Identiteter i forandring, Kulturstudier 12. Center for Kulturforskning, Århus Universitet, pp. 204226.

Gad, U.P. (2005). Dansksprogede grønlænderes plads i et Grønland under grønlandisering og modernisering. En diskursanalyse af den grønlandske sprogdebat - læst som identitetspolitisk forhandling. Eskimologis Skrifter, no. 19.

Gad, U.P. (2009a). Post-colonial identity in Greenland? When the Empire dichotomizes back - bring Politics back in. Journal of Language and Politics, vol. 8(1), pp. 136-158.

Gad, U.P. (2009b). Un avenir postcolonial groenlando-danois? Trois scénarios pour la dissolution de la Communauté du royaume - et trois autres pour son maintien et sa modification. Nordiques, no. 18, pp. 69-87.

Gad, U.P. (2016). National identity politics and postcolonial sovereignty games. Greenland, Denmark and the EU. Monographs on Greenland 353 [Man \& Society 43], Museum Tusculanum Publishers, Copenhagen.

Gad, U.P. (forthcoming). 'Grønlandsk identitet og udvikling - danske trusler og muligheder. Sprogdebatten under hjemme- og selvstyre. In: G. Tróndheim, O Marquardt and O. Høiris (eds.). Grønlcendernes syn på Danmark, danskere og dansk sprog og kultur. Aarhus: Aarhus Universitetsforlag.

Gad, U.P. and Petersen, K.L. (2011). Introduction: Concepts of Politics in Securitization Studies. Security Dialogue, vol. 42(4-5), pp. 315-328. 
Hall, S. (1996). Introduction: Who Needs "Identity"?. In: S. Hall and P. du Gay (eds,). Questions of Cultural Identity. London: Sage Publications, pp. 1-17.

Inatsisartut, negotiations, volumes 2002 and 2016. Available at: inatsisartut.gl.

Langgård, K. (2002). Fjeld, elv og hav. Natursynet i "Tarrarsuummi tarraq/Saltstøtten". In: E. Janussen et al. (eds). Grønlandsk kultur- og samfundsforskning 2000/01. Nuuk: Ilisimatusarfik/Atuagkat, pp. 73-98.

Langgård, K. (2003). Language policy in Greenland. In: J. Brincat, W. Boeder and T. Stolz (eds.). Purism in minor languages, endangered languages, regional languages, mixed languages. Papers from the conference on 'Purism in the Age of Globalisation', Bremen, September 2001. Bochum: Brockmeyer, pp. 225-256.

Larsen, F.B. (1992). The quiet life of a revolution: Greenlandic Home Rule 1979 - 1992. Études/Inuit/Studies, vol. 16(1-2), pp.199-226.

Manniche, J.C. (2003). Den store og den lille kolonialisme - Grønlands kolonihistorie i internationalt lys?. In: D. Thorleifsen (ed.). De vestnordiske landes falleshistorie. Udvalg af betragtninger over dele af den vestnordiske falleshistorie. Inussuk Arktisk forskningsjournal no. 2. Nuuk: KIIIP, pp. 117-124

Minister of Education. (2014). 'Welcome address', Put a Saga on your Screen conference, Akureyri, Iceland, 18-24 October. Available at: https://eng.menntamalaraduneyti.is/frontpage-stjr/nr/2819 [Accessed 3 July 2017].

Øverland, E.F. and Neumann, I.B. (2004). International Relations and Policy Planning: The Method of Perspectivist Scenario Building. International Studies Perspectives, vol. 5(3), pp. 258-277.

Petterson, C. (2014). The Missionary, the Catechist, and the Hunter. Foucault, Protestantisn and Colonialities. Studies in Critical Research on Religion 4, Brill, Leiden.

Roe, P. (2008). Securitizing Saddam: Actor, Audience(s) and Emergency Measures in the UK's Decision to Invade Iraq. Security Dialogue, vol. 39(6), pp. 615-635.

Rosing, M. et al. 2014 Til gavn for Grønland, Ilisimatusarfik, Nuuk/University of Copenhagen, Copenhagen. Available at:

http://greenlandperspective.ku.dk/this_is_greenland_perspective/background/report-papers/To_the_benefit_of_Greenland.pdf [Accessed 3 July 2017].

Sejersen, F. (1999). At være grønlænder - hvem sætter grænserne?. In: J. Lorentzen et al. (eds). Inuit, kultur og samfund - en grundbog i eskimologi. Aarhus: Systime, pp. 126-131.

Sermitsiaq, weekly, volumes 2002 and 2016.

Sørensen, B.W. (1991). Sigende tavshed. Køn og Etnicitet i Nuuk, Grønland. Antropologi, no. 24, pp. 41-58.

Sørensen, B.W. (1994). Magt eller afmagt? Køn, følelser og vold i Grønland. København: Akademisk Forlag. 
Thomsen, H. (1996). Between Traditionalism and Modernity. In: B. Jacobsen (ed.). Cultural and Social Research in Greenland 95/96. Essays in honour of Robert Petersen. Nuuk: Ilisimatusarfik/Atuakkiorfik, pp. 265-278.

Thuesen, S. (1988). Fremad, opad. Kampen for en moderne grønlandsk identitet. København: Rhodos.

Wæver, O. (1994). Insecurity and Identity Unlimited, Working Papers 14, COPRI, Copenhagen.

Wæver, O. (1995). Securitization and Desecuritization. In: R.D. Lipschutz (ed.). On Security. New York: Columbia University Press, pp. 46-87.

Wæver, O. (2003). Securitisation: Taking stock of a research programme in Security Studies, mimeo, February, Department of Political Science, University of Copenhagen.

Wæver, O. (2009a). Klimatruslen: En sikkerhedsteoretisk analyse. Politik, vol. 12(1), pp. $5-26$.

Wæver, O. (2009b). What exactly makes a continuous existential threat existential and how is it discontinued?. In: O. Bark and G. Sheffer (eds.). Existential Threats and Civil Security Relations. Lanham, Md: Lexington Books, pp. 19-36.

Wæver, O. (2011). Politics, Security, Theory. Security Dialogue, vol. 42(4-5), pp. 465480.

Wæver, O. (2015). The Theory Act: Responsibility and exactitude as seen from securitization. International Relations, vol. 29(1), pp. 121-127.

Wæver, O. and Sheikh, M. (2012).'Global Conflict and Security. In: M. Juergensmeyer and H. Anheier (eds.). The Encyclopedia of Global Studies. Thousand Oaks, CA: Sage Publications, pp. 645-653.

Werner, W.G. (1998). Securitisation and Legal Theory, Working Papers 27, COPRI, Copenhagen.

Žižek, S. (1992 [1990]). Eastern Republics of Gilead. In: C. Mouffe (ed.). Dimensions of Radical Democracy. London: Verso, pp. 193-207. 